\title{
Synthesis of New Organoselenium Compounds Containing Nucleosides as Antioxidant
}

\author{
LAILA M. BREAK ${ }^{1}$, MAHMOUD A. MOHAMED ${ }^{1,2}$ and SHAMS H. ABDEL-HAFEZ ${ }^{11,3}$ \\ 'Department of Chemistry, Faculty of Science, Taif University, Taif, Saudi Arabia. \\ ${ }^{2}$ Department of Biochemistry, Faculty of Agriculture, Cairo University, Cairo, Egypt. \\ ${ }^{3}$ Department of Chemistry, Faculty of Science, Assiut University, Assiut, Egypt. \\ ${ }^{*}$ Corresponding author E-mail: lailabreak@ hotmail.com
}

http://dx.doi.org/10.13005/ojc/300423

(Received: July 30, 2014; Accepted: September 26, 2014)

\begin{abstract}
Selenium containing nucleosides derived from some heterocyclic moieties such as Pyridineselenol, and pyridazineselenol is described herein. Ribosylation of selenol compounds were prepared in good yield by silyation of selenol derivatives with 1-O-acetyl-2,3,5-tri-O-benzoyl$\beta$-D-ribofuranose followed by debenzoylation to afford the corresponding free $\mathrm{N}$-nucleosides $\beta$ and $\alpha$-1-(2,3,5-trihydroxy- $\beta$-D-ribofuranosyl)-2-seleno-4,6-dimethylpyridine-3-carbonitrile (6a,7a); $b$ and $a-1-(2,3,5$-trihydroxy- $\beta$-D-ribofuranosyl)-3-seleno-5,6-diphenylpyridazine-4-carbonitrile $(6 b, 7 b)$. Newly synthesized compounds were characterized using the well known spectroscopic tools (IR, ${ }^{1} \mathrm{HNMR},{ }^{13} \mathrm{CNMR}$ and mass spectroscopy). Antioxidant activity of six selenonucleoside compounds ( $1 \mathrm{a} ; 6 \mathrm{a} ; 7 \mathrm{a} ; 1 \mathrm{~b} ; 6 \mathrm{~b}$ and $7 \mathrm{~b}$ ) was evaluated by animal assay model using experimental mice. The resulted data revealed that compounds $6 \mathrm{a}$ and $7 \mathrm{~b}$ showed to be more active as antioxidant with a better performance of scavenging ability than the other compounds.
\end{abstract}

Key words: 1-O-Acetyl-2,3,5-trihydroxy- $\beta$-D-ribofuranose; Nucleosides; Selenium ; Pyridineselenol; pyridazineselenol; antioxidants

\section{INTRODUCTION}

From the literature survey indicates that few publications have mentioned the incorporation of selenium atom into nucleosides ${ }^{1,2}$. In this paper ${ }^{1}$ describe the synthesis of selenium- and telluriumcontaining nucleosides, derived from uridine which was prepared in a concise and short synthetic route in good yields, by nucleophilic substitution of a tosylate group by organoselenium nucleophiles. On the other hand in previous work in our laboratory ${ }^{2}$ describes the synthesis of selenium-containing nucleoside analogues, derived from some heterocyclic moieties such as pyridineselenol, pyridazineselenol and quinolineselenol derivatives which indicated that one of pyridine-moiety $2-(1,3-$ dihydroxypropylselenyl)-4,6-dimethylpyridine-3carbonitrile which bearing two hydroxyl groups, and 
three of pyridazine-moieties 3-(3-hydroxypropyl selenyl)-5,6-diphenylpyridazine-4-carbonitrile, 3(1,3-dihydroxy propyl selenyl)-5,6diphenylpyridazine-4-carbonitrile and 3-(oxiran-2ylmethyl selenyl)-5,6-diphenyl- pyridazine-4carbonitrile respectively have definite antioxidant effect.

Stimulated by our recent work on the synthesis of selenium containing nucleoside analogues ${ }^{2}$, sulfa drugs ${ }^{3}$, and the synthesis of selenium containing amino acid analogues ${ }^{4}$, we decided to expand our interest to the introduction of an organoselenium compounds in the nucleoside framework and screened their biological activity as antioxidants.

\section{RESULTS AND DISCUSSION}

\section{Chemistry}

Ribosylation of $1 \mathrm{a}, \mathrm{b}$ were achieved by refluxing in hexamethyldisilazane (HMDS) to give the silylated derivatives $2 a$, b. The latter was stirred with 1-O-acetyl-2,3,5-O-benzoyl- $\beta$-D-ribofuranose (3) in the presence of dry 1,2-dichloroethane as a solvent using trimethylsilyl trifluoromethane sulfonate (TMS Triflate) $\left(\mathrm{CF}_{3} \mathrm{SO}_{2} \mathrm{OSiMe}_{3}\right)$ as a catalyst as according to the method of Vorbruggen et al., ${ }^{5}$ to give the corresponding mixture of $\beta$ anomeric protected $\mathrm{N}$-nucleoside derivatives and a-anomeric protected $\mathrm{N}$-nucleoside. Separation of the mixture of $\beta$ and $a$ anomers $(4 a, 5 a)$ and (4b, $5 b)$ was carried out by column chromatography in yields ranging from $25-75 \%$ of the corresponding benzoylated nucleosides (4a, 5a, 4b, and 5b) respectively (Scheme 1).

Debenzoylation of compounds (4a, 5a, $4 \mathrm{~b}$ and $5 \mathrm{~b}$ ) were performed by using methanolic sodium methoxide solution following Zemplen et al. method ${ }^{6}$ to afford the free nucleosides $(6 \mathrm{a}, 7 \mathrm{a}$, $6 \mathrm{~b}$ and $7 \mathrm{~b}$ ) respectively.

The chemical structures of the nucleoside derivatives $4 a, 4 b, 5 a, 5 b, 6 a, 6 b, 7 a$ and $7 b$ were established and confirmed on the basis of their elemental analyses and spectral data $\left(\mathrm{IR},{ }^{1} \mathrm{H}\right.$ and ${ }^{13} \mathrm{C}$ NMR) (see the Experimental section).

The IR spectra of compounds $(4 a, 5 a, 4 b$ and $5 b$ ) were observed at $v 2210 \mathrm{~cm}^{-1}$ due to $\mathrm{CN}$ group and stretching vibration frequencies of the benzoyl carbonyl groups $\mathrm{C}=\mathrm{O}$ appeared at $v 1740$, 1730, 1727 and $1724 \mathrm{~cm}^{-1}$ of compounds 4a, 5a,

Table 1: Effects of synthesized compounds (1a; $6 a ; 7 a$; 1b; 6 b and 7b) on SOD; GST activities and GSH-Rd levels

\begin{tabular}{lccc}
\hline Design of treatment & $\begin{array}{c}\text { SOD } \\
\text { (Units/mg protein) }\end{array}$ & $\begin{array}{c}\text { GST } \\
(\mu \text { mol /mgprotein) }\end{array}$ & $\begin{array}{c}\text { GSH-Rd } \\
(\mathbf{m g} / \mathbf{g} \text { protein) }\end{array}$ \\
\hline Untreated group,Group 1 & $35.13 \pm 1.25^{\mathrm{a}, \mathrm{b}}$ & $5.13 \pm 0.11^{\mathrm{a}, \mathrm{b}}$ & $4.21 \pm 0.21^{\mathrm{a}, \mathrm{b}}$ \\
Compound 1a (100 mg/kg) (Group 2) & $35.87 \pm 0.51$ & $5.84 \pm 0.11$ & $4.10 \pm 0.10$ \\
Compound 1a (200 mg/kg) (Group 3) & $32.21 \pm 1.93$ & $6.13 \pm 0.25$ & $5.01 \pm 0.32$ \\
Compound 1b (100 mg/kg) (Group 4) & $34.39 \pm 1.13$ & $5.10 \pm 0.61$ & $4.91 \pm 0.27$ \\
Compound1b (200 mg/kg) (Group 5) & $33.90 \pm 1.21$ & $5.82 \pm 0.18$ & $5.11 \pm 0.22$ \\
Compound 6a (100 mg/kg) (Group 6) & $39.01 \pm 1.15^{\mathrm{a}, \mathrm{b}}$ & $3.91 \pm 0.26^{\mathrm{a}, \mathrm{b}}$ & $5.85 \pm 0.13^{\mathrm{a}, \mathrm{b}}$ \\
Compound 6a (200 mg/kg) (Group 7) & $38.90 \pm 1.01^{\mathrm{a}, \mathrm{b}}$, & $6.19 \pm 0.10^{\mathrm{a}, \mathrm{b}}$ & $5.39 \pm 0.11^{\mathrm{a}, \mathrm{b}}$ \\
Compound 6b (100 mg/kg) (Group 8) & $32.49 \pm 2.10$ & $5.01 \pm 0.72^{\mathrm{b}}$ & $4.01 \pm 0.12$ \\
Compound 6b (200 mg/kg) (Group 9) & $33.54 \pm 1.42$ & $4.45 \pm 0.11$ & $3.92 \pm 0.15$ \\
Compound 7a (100 mg/kg) (Group 10) & $34.54 \pm 2.10$ & $5.12 \pm 0.32$ & $4.78 \pm 0.17$ \\
Compound 7a (200 mg/kg) (Group 11) & $31.97 \pm 1.79$ & $5.16 \pm 0.40$ & $4.98 \pm 0.13$ \\
Compound 7b (100 mg/kg) (Group 12) & $41.54 \pm 1.15^{\mathrm{a}, \mathrm{b}}$ & $7.12 \pm 0.81^{\mathrm{a}, \mathrm{b}}$ & $6.78 \pm 0.14^{\mathrm{a}, \mathrm{b}}$ \\
Compound 7b (200 mg/kg) (Group1 3) & $39.17 \pm 1.02^{\mathrm{a}, \mathrm{b}}$ & $6.82 \pm 0.42^{\mathrm{a}, \mathrm{b}}$ & $6.18 \pm 0.08^{\mathrm{a}, \mathrm{b}}$ \\
Vitamin E (100 mg/ kg) (Group 14) & $45.17 \pm 1.13$ & $8.12 \pm 0.11$ & $7.37 \pm 0.31$ \\
\hline
\end{tabular}

Values are mean $\pm S D, n=6$, ab the difference is significant $(p>0.05)$ in a column between treated and untreated control group1. 
$4 \mathrm{~b}$ and $5 \mathrm{~b}$ respectively. In addition signals at $v 1625$, $1620 \mathrm{~cm}^{-1}$ for the $\mathrm{C}=\mathrm{N}$ group of compounds $4 \mathrm{a}, 5 \mathrm{a}$, and at $v 1630 \mathrm{~cm}^{-1}$ of compounds $4 \mathrm{~b}$ and $5 \mathrm{~b}$.

The IR spectra and the most important peaks for compounds (6a, 7a, 6b and $7 b$ ) were observed at $v 3400-3450 \mathrm{~cm}^{\prime \prime}$ due to ( $\mathrm{OH}$ group) for compounds $6 \mathrm{a}$ and $6 \mathrm{~b}$ respectively and signals at $v 3380 \mathrm{~cm}^{-1}$ due to ( $\mathrm{OH}$ group) for compounds $7 \mathrm{a}$ and $7 \mathrm{~b}$.

The $1 \mathrm{H}$ NMR spectra of compounds (4a, $5 a, 4 b$ and $5 b)$ showed a doublet ranging from $v$ 5.55 - 6.39 ppm, with spin-spin coupling constant $\left(v_{1,2}\right)$ equal to $7.5 \mathrm{~Hz}$ for proton $\left(\mathrm{H}-1^{\prime}\right)$ which confirms the $\beta$-anomeric configuration of compound $4 \mathrm{a}$ and $4 \mathrm{~b}$ respectively, while the data showed that a doublet signals at $\delta$ ranging from $5.80-6.39$ ppm , with spin-spin coupling constant $\left(\mathrm{J}^{\prime}, 2, \mathrm{2}^{\prime}\right)$ ranging from 4.5-5 $\mathrm{Hz}$ for proton $\left(\mathrm{H}-1^{\prime}\right)$ assigned to the a anomeric configuration of compound $5 \mathrm{a}$ and $5 \mathrm{~b}$ respectively.

The $1 \mathrm{H}$ NMR spectra of compounds (6a, $7 \mathrm{a}, 6 \mathrm{~b}$ and $7 \mathrm{~b}$ ) showed a doublet ranging

From $\delta$ 6.20-6.08 ppm with $\left(J_{1,2}\right)$ equal to 7-7.5 Hz for for proton $\left(\mathrm{H}-1^{\prime}\right)$ which confirms the ${ }^{2}$ anomeric configuration of compound $6 \mathrm{a}$ and $6 \mathrm{~b}$. While signals at $5 \varnothing$ ÿp ranging from $6.08-6.22$ ppm, with spin-spin coupling constant $\left(\mathrm{J}_{1^{\prime}, 2^{\prime}}\right)$ ranging from 5.5-5 $\mathrm{Hz}$ for proton $\left(\mathrm{H}-1^{\prime}\right)$ assigned to the a anomeric configuration of compound $7 \mathrm{a}$ and $7 \mathrm{~b}$ respectively.

The 13C NMR spectrum of compounds (4a, b, 5a, b, 6a, b and 7a, b) showed the most signals at $\delta \mathrm{C} 13.4$ and 18.6 for two groups of $\mathrm{CH}_{3}$ for compounds $4 \mathrm{a}$ and $5 \mathrm{a}$. The five signals at $\delta \mathrm{C}$ $93.2,84.2,78.1,71.4$ and 59.2 were assigned to C-1', C-2' , C-3' , C-4', and C-5' of the sugar moiety, respectively. Data showed that at $\delta \mathrm{C} 118.2$ due to (CN), 120.0-135.0 (Ar), 151.2, 160.2, $168.0(\mathrm{C}=\mathrm{O})$; $175.0(\mathrm{C}=\mathrm{Se})$ of compound $4 \mathrm{a}$ and $175.9(\mathrm{C}=\mathrm{Se})$ of compound $4 \mathrm{~b}$. The $13 \mathrm{C}$ NMR spectrum of compounds $7 \mathrm{a}$ and $7 \mathrm{~b}$ showed signals: 22.63 , 29.70, 52.15, 63.42, 76.12, 79.11, 84.71, 117.786, $128.39,129.74,132.09,133.26,169.79$ for $7 a$ and signals at $\delta 52.12,64.50,76.12,79.11,89.51$, $117.53,127.34,128.28,128.36,128.65,128.88$, $128.99,129.57,132.06,132.92,133.23,134.13$, $167.72,169.27$ for $7 b$

Finally the Mass spectra and Elemental analysis are in agreement and confirmed of all new compounds.

\section{Biological activity \\ Toxicity studies}

Toxicity parameters including $\mathrm{LD}_{50}$; GPT

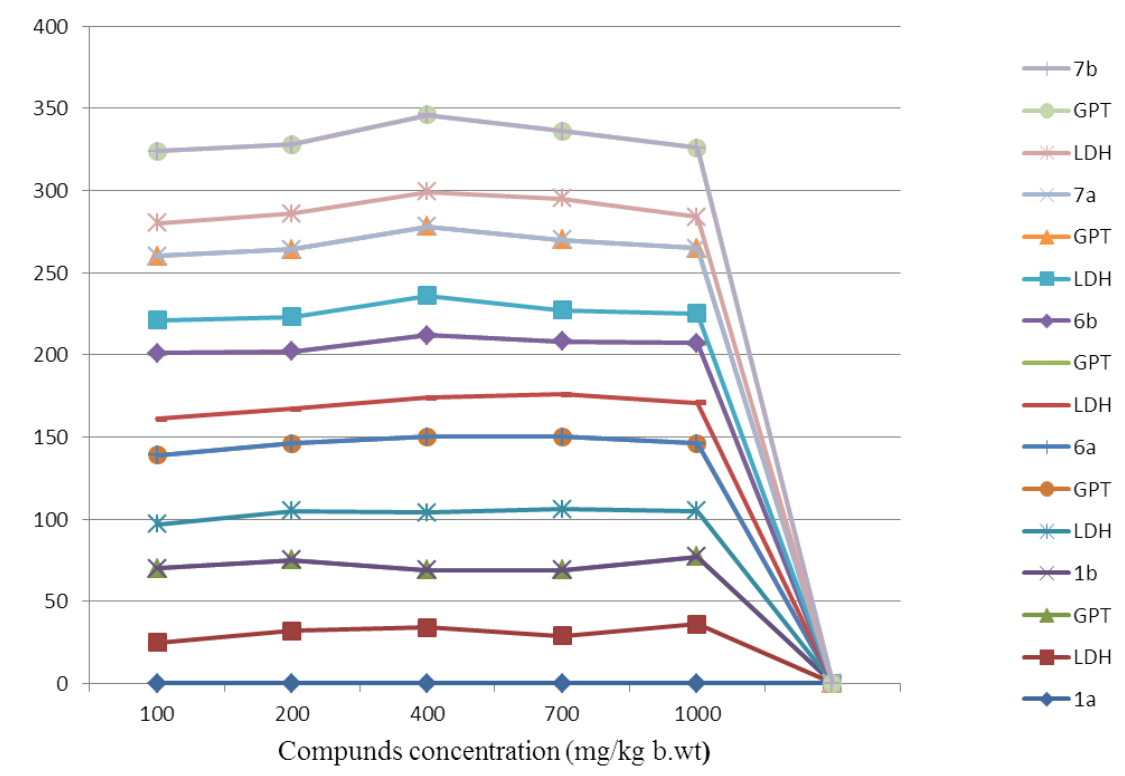

Fig. 1: Effects of synthesized compounds on activities of GPT and LDH enzymes 
and LDH activities were determined and ranged in normal limits compared to infected untreated group with concentrations range up to $1000 \mathrm{mg} \mathrm{kg}$ - b.wt. The GPT, an enzyme which allows determining the liver function as indicator on liver cells damage and $\mathrm{LDH}$ enzyme is often used as a marker of tissue breakdown (Butt et al., 2002) [6].

\section{Antioxidant activity evaluation}

Hepatic GSH-Rd and serum activities of SOD, GSH-S-transferase levels were measured as an indicator of antioxidant activity and result are present in Table 1. SOD and GSH-S-transferase are antioxidant enzymes that protect cells from oxidative stress of highly reactive free radicals and induces on the generation of free radicals in living cells. Result indicated that significant increasing $(p<0.05)$ in SOD, and GST activities in the treated groups at doses of 100 and $200 \mathrm{mg} / \mathrm{kg}$ compared to un-treated control group. No significant deference found between used doses (100 and $200 \mathrm{mg} / \mathrm{kg}$ ) with all tested compounds. The highest SOD and GST, activities rather than GSH-Rd levels was monitored in animals treated with compounds $6 \mathrm{a}$ and $7 \mathrm{~b}$. (See Table 1, Fig. 1).

\section{EXPERIMENTAL}

\section{General}

Melting points were determined by using the Kofler melting point apparatus, and were uncorrected. IR $\left(\mathrm{KBr}, \mathrm{cm}^{-1}\right)$ spectra were recorded on a Pye-Unicam SP3-100 instrument at Taif University. 1H NMR spectra were obtained on a Varian (400 MHz) EM 390 USA instrument at King Abdel-Aziz University by using TMS as internal reference.13 C NMR spectra were recorded on a JNM-LA spectrometer (100 MHz) at King Abdel-Aziz University, Saudi Arabia. Elemental analyses were obtained on an Elementar Vario EL 1150C analyzer. Mass spectra were recorded on a JEOL-JMS-AX 500 at Cairo National Research Center, Cairo, Egypt. Purity of the compounds was checked by thin layer chromatography (TLC) using silica gel plates.

Synthesis of $a$ and b-1-(-(2,3,5-tri-O-benzoyl- $\beta-D-$ ribofuranosyl)seleno derivatives $(4 a, b, 5 a, b)$

Ribosylation of 2-seleno-4,6dimethylpyridine-3-carbonitrile and 3-seleno-5,6- diphenylpyridazine-4-carbonitrile (1a,b). Synthesis of $b$ and a-1-(2,3,5-tri-O-benzoyl- $\delta$-D-ribofuranosyl) -2-seleno-4,6-dimethylpyridine-3-carbonitrile (4a, $5 a) ; b$ and a- $\delta 1-(2,3,5-t r i-O-b e n z o y l-5 \varnothing y ́ P-D-$ ribofuranosyl)-3-seleno-5,6-diphenylpyridazine-4carbonitrile (4b, 5b).

General Procedure. A mixture of 2-seleno4,6- dimethylpyridine-3-carbonitrile or 3-seleno-5,6diphenylpyridazine-4-carbonitrile (1a,b) (0.02 mol) and hexamethyl di- silazane $(20 \mathrm{ml})$ was heated under reflux for $24 \mathrm{~h}$ with a catalytic amount of ammonium sulfate $(0.01 \mathrm{~g})$. After that, the clear solution was cooled and evaporated till dryness to give the silyated derivative $(2 a, b)$, which directly was dissolved in $20 \mathrm{ml}$ of dry 1,2-dichloroethane and then 1-O-acetyl-2,3,5-tri-O-benzoyl-Dribofuranose (3) $(5.05 \mathrm{~g}, 0.01 \mathrm{~mol})$ was added. The mixture was added dropwise onto a mixture of (10 $\mathrm{ml}$ trimethylsilyl trifluoromethanesulfonate (Triflate) in dry 1,2-dichloroethane $(50 \mathrm{ml})$ ). All mixture was stirred at room temperature for $24 \mathrm{~h}$, and then washed with a saturated solution of aqueous sodium bicarbonate $(3 \times 50 \mathrm{ml})$, washed with water $(3 \times 50 \mathrm{ml})$, and dried over anhydrous sodium sulfate. The solvent was removed in vacuum and the residue was chromatographic on silica gel with chloroform: ethyl acetate (9: 1) as eluent to afford a white crystal from pure anomeric $b$ and colorless crystals from a anomeric (4a,b and $5 a, b)$ respectively.

\section{Compound (pydBzb) (4a)}

Yield (42\%), m.p. 160-161'"C; IR (KBr) $\beta$ $\mathrm{cm}^{-1}: 2217(\mathrm{CN}), 1730$ (CO). ${ }^{1} \mathrm{H}$ NMR $\left(\mathrm{CDCl}_{3}\right): \beta 3.19$ (s, $\left.3 \mathrm{H}, \mathrm{CH}_{3}\right) ; 2.20\left(\mathrm{~s}, 3 \mathrm{H}, \mathrm{CH}_{3}\right) ; 3.98-4.10(\mathrm{~m}, 2 \mathrm{H}$, $\left.2 \mathrm{H}^{-} 5^{\prime}\right) ; 4.90\left(\mathrm{~m}, 1 \mathrm{H}, 1 \mathrm{H}-4^{\prime}\right), 5.25-5.30\left(\mathrm{~m}, 1 \mathrm{H}, \mathrm{H}-3^{\prime}\right)$, 5.38-5.40 (m, 1H, H-2'), $5.55\left(\mathrm{~d}, 1 \mathrm{H}, \mathrm{H}-1^{\prime}, \beta=\mathrm{J}_{1^{\prime}, 2^{\prime}}=\right.$ $7.5 \mathrm{~Hz}$ ), 6.32 (s, 1H, CH-pyridine), 7.33-8.05 (m, $15 \mathrm{H}$, aromatic protons); ${ }^{13} \mathrm{CNMR}\left(\mathrm{CDCl}_{3}\right): 16.2,20.3$, 59.2, 71.4, 78.1, 84.2, 93.2, 118.2, 120.0-135.0, 151.2,160.2, 168.0; 175.0 (C=Se). Anal. Calcd. for $\mathrm{C}_{34} \mathrm{H}_{28} \mathrm{~N}_{2} \mathrm{O}$ Se (655.56): C, 62.29; H, 4.31; N, 4.27 (\%); Found: C, 62.00; H, 4.11; N, 4.14 (\%).

Compound (pydBza) (5a)

Yield (28\%), m.p. 203-204'C; IR (KBr) v $\mathrm{cm}^{-1}: 2210$ (CN), 1730 (CO). ${ }^{1} \mathrm{H}$ NMR $\left(\mathrm{CDCl}_{3}\right): 3.12$ (s, 3H, $\left.\mathrm{CH}_{3}\right) ; 2.23$ (s, 3H, $\left.\mathrm{CH}_{3}\right) ; 3.46-3.48(\mathrm{~m}, 2 \mathrm{H}$, $\left.2 \mathrm{H}-5^{\prime}\right), 4.60-4.95\left(\mathrm{~m}, 1 \mathrm{H}, \mathrm{H}-4^{\prime}\right), 5.15-5.30(\mathrm{~m}, 1 \mathrm{H}$, 
$\left.\mathrm{H}^{-3}\right)$, 5.40-5.60 (m, 1H, H-2'), 5.80-6.94 (d, 1H, H$\left.1^{\prime}, \mathrm{J}_{1^{\prime}, 2^{\prime}}=4.5 \mathrm{~Hz}\right), 6.30$ (s, 1H, CH-pyridine), 8.00$7.45(\mathrm{~m}, 15 \mathrm{H}, \mathrm{Ar}-\mathrm{H}) ;{ }^{13} \mathrm{C}$ NMR $\left(\mathrm{CDCl}_{3}\right): 13.4,18.6$, 59.5, 71.2, 78.1, 84.0, 93.2, 121.4, 125.0-140.2, 151.2, 159.2, 168.0, 175.2 (C=Se); Anal. Calcd. for $\mathrm{C}_{34} \mathrm{H}_{28} \mathrm{~N}_{2} \mathrm{O}_{7} \mathrm{Se}$ (655.56): C, 62.29; $\mathrm{H}, 4.31 ; \mathrm{N}, 4.27$ (\%); Found: C, 62.15; H, 4.22; N, 4.10 (\%).

\section{Compound (PydzBzß) (4b)}

Yield (47\%), m.p. 185-187-“C; IR (KBr) v $\mathrm{cm}^{-1}: 2210(\mathrm{CN}), 1730(\mathrm{CO}), 1630(\mathrm{C}=\mathrm{N}) ;{ }^{1} \mathrm{H}$ NMR $\left(\mathrm{CDCl}_{3}\right): \delta 4.23\left(\mathrm{~d}, 1 \mathrm{H}, \mathrm{H}-4^{\prime} \beta=\mathrm{J}_{1^{\prime}, 2^{\prime}}=7.5 \mathrm{~Hz}\right) ; 4.58-$ $4.57\left(\mathrm{~m}, 2 \mathrm{H}, \mathrm{H}-5^{\prime}\right), \quad 4.64\left(\mathrm{~d}, 1 \mathrm{H}, \mathrm{H}-3^{\prime}, 5 \varnothing=\mathrm{U} 1^{\prime}, 2^{\prime}=\right.$ $7.5 \mathrm{~Hz}) ; 5.65\left(\mathrm{~d}, 1 \mathrm{H}, \mathrm{H}-2^{\prime}, \mathrm{J}_{1^{\prime}, 2^{\prime}}=7.5 \mathrm{~Hz}\right), 6.39(\mathrm{~d}, 1 \mathrm{H}$, $\left.\mathrm{H}-1^{\prime}, \mathrm{J}_{1^{\prime}, 2^{\prime}}=7.5 \mathrm{~Hz}\right), 7.53-7.00-7.45(\mathrm{~d}, 10 \mathrm{H}$, aromatic protons, $\mathrm{J}=8.0 \mathrm{~Hz}), 8.05-7.81(\mathrm{~m}, 15 \mathrm{H}, \mathrm{Ar}-\mathrm{H})$; ${ }^{13} \mathrm{CNMR}\left(\mathrm{CDCl}_{3}\right): 59.1,71.5,78.3,84.2,93.0,121.2$, 125.0-140.0,151.2, 162.1, 168.4, 175.9 (C=Se); Anal. Calcd. for $\mathrm{C}_{43} \mathrm{H}_{31} \mathrm{~N}_{3} \mathrm{O}_{7} \mathrm{Se}$ (780.68): C, 66.15; H, 4.00; N, 5.38 (\%); Found: C, 66.08; H, 3.99; N, $5.10(\%)$.

\section{Compound (PydzBza) (5b)}

Yield (30\%), m.p. 168-169"'C; IR (KBr) vcm 1: 2210(CN), $1724(\mathrm{CO}), 1630(\mathrm{C}=\mathrm{N}) ;{ }^{1} \mathrm{H}$ NMR $\left(\mathrm{CDCl}_{3}\right): \delta 4.23\left(\mathrm{~d}, 1 \mathrm{H}, \mathrm{H}-4^{\prime} 5 \varnothing=\mathrm{U}_{1^{\prime}, 2^{\prime}}=7.5 \mathrm{~Hz}\right) ; 4.58-$ $4.57\left(\mathrm{~m}, 2 \mathrm{H}, \mathrm{H}-5^{\prime}\right), \quad 4.64\left(\mathrm{~d}, 1 \mathrm{H}, \mathrm{H}_{-} 3^{\prime}, 5 \varnothing=\mathrm{U} 1^{\prime}, 2^{\prime}=\right.$ $7.5 \mathrm{~Hz}) ; 5.65\left(\mathrm{~d}, 1 \mathrm{H}, \mathrm{H}-2^{\prime}, \mathrm{J}_{1^{\prime}, 2^{\prime}}=7.5 \mathrm{~Hz}\right), 6.39(\mathrm{~d}, 1 \mathrm{H}$, $\left.\mathrm{H}-1^{\prime}, \mathrm{J}_{1^{\prime}, 2^{\prime}}=5.0 \mathrm{~Hz}\right), 7.53-7.00-7.45(\mathrm{~d}, 10 \mathrm{H}$, aromatic protons, $\mathrm{J}=8.0 \mathrm{~Hz}), 8.05-7.81(\mathrm{~m}, 15 \mathrm{H}, \mathrm{Ar}-\mathrm{H}) \cdot{ }^{13} \mathrm{C}$ NMR $\left(\mathrm{CDCl}_{3}\right): 35.2,59.1,71.0,78.3,84.4,93.2$, 121.0, 125.1-140.0, 151.3, 160.4, 168.1, 175.5 (C=Se); Anal. Calcd. for $\mathrm{C}_{43} \mathrm{H}_{31} \mathrm{~N}_{3} \mathrm{O}_{7} \mathrm{Se}(780.68)$ : C, 66.15; H, 4.00; N, 5.38 (\%); Found: C, 66.00; H, 3.98; N, 5.30 (\%).

Deprotection of $4 a, b$ and $5 a, b$. Synthesis of nucleosides $6 a, b$ and $7 a, b$ respectively.

General Procedure

A mixture of each protected nucleoside $4 a, b$ and $5 a, b(0.001 \mathrm{~mol}$ for each), absolute methanol $(20 \mathrm{ml})$ and sodium methoxide $(0.055 \mathrm{~g}$, $0.001 \mathrm{~mol}$ ) was stirred at room temperature for $48 \mathrm{~h}$. The solvent was evaporated under vacuum to give a colorless solid, which was dissolved in hot water and neutralized with acetic acid. The precipitate compound was chromatographic on silica gel with chloroform: ethyl acetate (9: 1) as eluent to afford colorless and white crystals of the corresponding nucleosides $6 a, b$ and $7 a, b$ respectively.

\section{Compound (PydOHb)(6a)}

Yield (35\%), m.p. 210-212 'C; IR (KBr) vcm 1: $3400(\mathrm{OH}), 2215(\mathrm{CN}) ;{ }^{1} \mathrm{H}$ NMR (DMSO-5ØQÜ6): $5 \varnothing$ ӱР $3.27\left(\mathrm{~s}, 3 \mathrm{H}, \mathrm{CH}_{3}\right), 2.33\left(\mathrm{~s}, 3 \mathrm{H}, \mathrm{CH}_{3}\right), 3.55-$ $3.65\left(\mathrm{~m}, 2 \mathrm{H}, 5^{\prime}-\mathrm{H}\right), 3.92-3.90\left(\mathrm{~m}, 1 \mathrm{H}, 4{ }^{\prime}-\mathrm{H}\right), 4.15-$ $4.25\left(\mathrm{~m}, 1 \mathrm{H}, 3^{\prime}-\mathrm{H}\right), 4.53-4.54\left(\mathrm{~m}, 1 \mathrm{H}, 2^{\prime}-\mathrm{H}\right), 4.75-$ 5.85 (s, 3H, 3-OH), 6.20 (d, 1H, J 1', $^{\prime}=7.5 \mathrm{~Hz}, 1^{\prime}-\mathrm{H}$ ), 6.30 (s, $1 \mathrm{H}, \mathrm{CH}$-pyridine). ${ }^{13} \mathrm{C} \mathrm{NMR}\left(\mathrm{CDCl}_{3}\right)$ : 20.26, 24.63, 61.33, 71.2, , 78.1, 84.0, 109.63, 115.786, $122.79,127.34,132.04,151.95,162.48$; Anal.Calcd. for $\mathrm{C}_{13} \mathrm{H}_{16} \mathrm{~N}_{2} \mathrm{O}_{4} \mathrm{Se}$ (343.24): C, 45.49; $\mathrm{H}$, 4.70; N, 8.16 (\%); Found: C, 45.15; H, 4.50; N, 8.07 (\%).

\section{Compound (PydOHa)(7a)}

Yield (27\%), m.p. 215-217“"C; IR (KBr) v"1: $3380(\mathrm{OH}), 2217$ (CN); ${ }^{1} \mathrm{H}$ NMR (DMSO-d6): $\delta 3.25$ (s, 3H, $\left.\mathrm{CH}_{3}\right), 2.28\left(\mathrm{~s}, 3 \mathrm{H}, \mathrm{CH}_{3}\right), 3.47-3.48\left(\mathrm{~m}, 2 \mathrm{H}, 5^{\prime}-\right.$ $\mathrm{H})$, 3.9-3.92 (m, 1H, 4'-H), 4.05-4.12 (m, 1H, 3'-H), 4.35-4.45 (m, 1H, 2'-H), 4.75-5.85 (s, 3H, 3-OH, 6.22 (d, $\left.1 \mathrm{H}, \mathrm{J}_{, 2}=5.5 \mathrm{~Hz}, 1^{\prime}-\mathrm{H}\right), 6.35$ (s, 1H, CH-pyridine). ${ }^{13} \mathrm{C}$ NMR $\left(\mathrm{CDCl}_{3}\right): 22.63,29.70,52.15,63.42,76.12$, 79.11, 84.71, 117.786, 128.39, 129.74, 132.09, 133.26, 169.79; Anal. Calcd. for $\mathrm{C}_{13} \mathrm{H}_{16} \mathrm{~N}_{2} \mathrm{O}_{4} \mathrm{Se}$ (343.24): C, 45.49; H, 4.70; N, 8.16; Found: C, 45.20; H, 4.29; N, 8.10(\%).

\section{Compound (PydzOHb)(6b)}

Yield (64\%), m.p.230-232 ${ }^{\circ} \mathrm{C}$; IR( $\left.\mathrm{KBr}\right) v \mathrm{~cm}^{-}$ 1: 3450(OH), $2210(\mathrm{CN}), 1630(\mathrm{C}=\mathrm{N}) ;{ }^{1} \mathrm{H}$ NMR (DMSO-d6): $\delta 1.25$ (s, 1H, 5'-OH), 1.66 (s, 1H, 3'-OH), 3.92 (s, 1H, 2'-OH), $4.28\left(\mathrm{~m}, 2 \mathrm{H}, 5^{\prime}-\mathrm{H}\right) ; 4.38(\mathrm{~m}, 1 \mathrm{H}$, 4'-H); $4.96\left(\mathrm{t}, 1 \mathrm{H}, 3^{\prime}-\mathrm{H}\right), 5.65\left(\mathrm{~d}, 1 \mathrm{H}, 2^{\prime}-\mathrm{H}\right), 6.08$ (d, $\left.1 \mathrm{H}, \mathrm{J}_{1^{\prime}, 2^{\prime}}=7.0 \mathrm{~Hz}, 1^{\prime}-\mathrm{H}\right), 7.26-8.05(\mathrm{~m}, 10 \mathrm{H}$, aromatic protons). ${ }^{13} \mathrm{C} \mathrm{NMR}\left(\mathrm{CDCl}_{3}\right): 66.81,72.74,82.90$, $88.52,91.42,117.78,128.54,128.59,129.40$, $129.45,129.55,130.11,130.38,131.14,132.83$, 133.19, 134.75,138.90, 167.77 ,168.52; Anal. Calcd. for $\mathrm{C}_{22} \mathrm{H}_{19} \mathrm{~N}_{3} \mathrm{O}_{4} \mathrm{Se}(468.36)$ : C, 56.42; $\mathrm{H}, 4.09 ; \mathrm{N}, 8.97$ (\%); Found: C, 55.95; H, 3.97; N, 8.72(\%).

\section{Compound (PydzOH $\alpha)(7 b)$}

Yield (75\%), m.p. 235-237'C; IR (KBr) vcm 1: $3380(\mathrm{OH}), 2210(\mathrm{CN}), 1630(\mathrm{C}=\mathrm{N}) .{ }^{1} \mathrm{H}$ NMR (DMSO- $\delta$ ): $\delta 1.25$ (s, $\left.1 \mathrm{H}, 5^{\prime}-\mathrm{OH}\right), 1.66\left(\mathrm{~s}, 1 \mathrm{H}, 3^{\prime}-\mathrm{OH}\right)$, 3.92 (s, 1H, 2'-OH), 4.28 (s, 2H, 5'-H); 4.38 (m, 2H, $\left.4^{\prime}-\mathrm{H}\right) ; 4.96\left(\mathrm{t}, 1 \mathrm{H}, 3^{\prime}-\mathrm{H}\right), 5.65\left(\mathrm{~d}, 1 \mathrm{H}, 2^{\prime}-\mathrm{H}\right), 6.08$ (d, $\left.1 \mathrm{H}, \mathrm{J}_{1^{\prime}, 2^{\prime}}=5.0 \mathrm{~Hz}, 1^{\prime}-\mathrm{H}\right), 7.26-8.05(\mathrm{~m}, 10 \mathrm{H}$, aromatic protons). ${ }^{13} \mathrm{C} \mathrm{NMR}\left(\mathrm{CDCl}_{3}\right): 52.12,64.50,76.12$, $79.11,89.51,117.53,127.34,128.28,128.36$, 
128.65, 128.88, 128.99, 129.57, 132.06, 132.92, 133.23, 134.13, 167.72, 169.27; Anal. Calcd. $\mathrm{C}_{22} \mathrm{H}_{19} \mathrm{~N}_{3} \mathrm{O}_{4} \mathrm{Se}$ (468.36): C, 56.42; H, 4.09; N, 8.97 (\%); Found: C, 56.10; H, 4.00; N, 8.50 (\%).

\section{Biological experiments. Chemicals}

Dimethyl sulfoxide (DMSO) and vitamin E were obtained from Sigma Chemical Co. (St. Louis, MO, USA). All enzymatic kits were purchased from Bioassays system, USA.

\section{Experimental animals}

Male Albino mice $(20 \pm 2 \mathrm{~g})$ were obtained from department of animal science, cairo university and animals were handled under standard laboratory conditions with a 12-h light/dark cycle in a temperature of $25 \pm \mathrm{C}$ and a relative humidity of $55 \pm 5 \%$ controlled room. The basal diet used in these studies was certified feed to research laboratories animals. Food and water were available adlibitum. Cairo university animal care and use committee approved all protocols for the animal studies research.

\section{Toxicity experiment}

Male Albino mice of 6 animals per group and weighing between $25 \pm 5 \mathrm{~g}$ were administered after overnight fasting with graded doses of (1001000) $\mathrm{mg} \mathrm{kg}^{-1} \mathrm{~b}$.wt. intra peritoneal of each individual synthesized compounds suspended in DMSO. The toxicological effects were observed after $72 \mathrm{~h}$ of treatment in terms of mortality and expressed as LD $_{50}$ (Ghosh, 1984) [8]. Others biochemical parameters determined after 14 days of administration according to methods of Reitman and Frankel (1957) [9] for GPT activity and Bergmeyer (1974) [10]for LDH activity

\section{Bioassays model design}

The animals were randomly divided into fourteen groups of 6 mice each. The first group served as untreated normal control. Group 2 to Group 13 on 7th day, animals were pre-treated with individual synthesized compounds at 100 and 200 $\mathrm{mg} / \mathrm{kg} \mathrm{b}$, wt, per day p.o., respectively for 7 days. Group 14, animals were pre-treated with standard drug Vitamin E (100 mg/ kg b, wt, per day p.o) for 7 days. (Rai et al., 2006) ${ }^{11}$.
Twenty-four hours after the last administration, mice were sacrificed. Blood samples were collected and centrifuged at $4000 \times \mathrm{g}$ at $4 æ \% \mathrm{C}$ for $10 \mathrm{~min}$ for serums preparation. The liver was removed rapidly, washed and homogenized in icecold physiological saline to prepare $10 \%(\mathrm{w} / \mathrm{v})$ homogenate. Then, the homogenate was centrifuged at $4000 \times \mathrm{g}$ at $4 æ \% \mathrm{C}$ for $10 \mathrm{~min}$ to remove cellular debris, and the supernatant was collected for biochemical analysis.

The biochemical assays.

Measurement of Glutathione-S-Transferase activity (GST)

GST activity was determined as described by Habig et al., (1974) ${ }^{12}$. Reaction mixture containing $50 \mathrm{mM}$ phosphate buffer, $\mathrm{pH} 7.5,1 \mathrm{mM}$ of 1-chloro2, 4 dinitrobenzene (CDNB) and a appropriate volume of compound solution. The reaction was initiated by the addition of reduced glutathione GSH) and formation of S-(2, 4-dinitro phenyl) glutathione (DNPGS) was monitored as an increase in absorbance at $334 \mathrm{~nm}$. The result was expressed as $\mu \mathrm{mol}$ of CDNB conjugation formed $/ \mathrm{mg}$ protein $/ \mathrm{min}$.

\section{Measurement of Super Oxide Dismutase (SOD) activity}

SOD activity was measured through the inhibition of hydroxylamine oxidation by the superoxide radicals generated in the xanthinexanthine oxidase system. (Kakkar et al. 1972) [13]. The results were expressed in units/mg protein.

\section{Measurement of Glutathione Reduced (GSH-Rd)} levels

GSH in liver and kidney tissues was determined according to the Ellman method (Ellaman, 1959) ${ }^{14}$, which measures the reduction of 5,50-dithio-bis (2-nitrobenzoic acid) (DTNB) (Ellman's reagent) by sulfhydryl groups to 2-nitro5-mercaptobenzoic acid, which has an intense yellow color. The results were expressed in $\mathrm{mg}$ per g protein ( $\mathrm{mg} / \mathrm{g}$ protein).

\section{Measurement of Protein content}

Protein levels were determined spectrophotometrically at $595 \mathrm{~nm}$, using comassie blue $\mathrm{G} 250$ as a protein binding dye (Bradford, $1976)^{15}$. Bovine serum albumin (BSA) was used as a protein standard. 


\section{CONCLUSION}

Silyation of selenol derivatives with 1-Oacetyl-2,3,5-tri-O-benzoyl- $\beta$-D-ribofuranose followed by debenzoylation affording the corresponding free $\mathrm{N}$-nucleosides compounds $\beta$ and $\alpha-1$-(2,3,5-trihydroxy- $b$-D-ribofuranosyl)-2seleno-4,6-dimethylpyridine-3-carbonitrile $(6 a, 7 a)$; $\beta$ and $\alpha-1-(2,3,5$-trihydroxy- $b$-D-ribofura- nosyl)3-seleno-5,6-diphenylpyridazine-4-carbonitrile $(6 \mathrm{~b}, 7 \mathrm{~b})$ respectively. Compounds $6 \mathrm{a}$ and $7 \mathrm{~b}$ showed to be more active as antioxidant with a better performance of scavenging ability than other compounds. The SOD activity of these molecules was compared with standard antioxidant (vitamin E). Selenonucleoside compounds are active sites of a large number of selenium dependent enzymes, such as antioxitant enzymes [Spallholz J.E 1994] [7]. The configuration structure of compounds $6 a$ and $7 \mathrm{~b}$ may more suitable for SOD and GST enzymes active center, so these compounds induce the antioxidants enzymes activity.

\section{REFERENCES}

1. L. Antonio Braga, a. Wolmar Severo Filho, S. Icardo Schwab, E. D. Oscar Rodrigues, D. Lucian, C. Hugo Braga, S. Diogo Ludtke, Tetrahedron lett. 2009, 50, 3005-3007.

2. Sh. H. Abdel-Hafez, H. A. Saad, M. A. Mohamed. Der Pharma Chemica, 2012, 4(3):915-925.

3. Sh. H. Abdel-Hafez. Rus. J. Bioorg. Chem., 2010; 36(3): pp. 370-376.

4. Sh. H. Abdel-Hafez, Saad, H.A., Aly, M.R.E. Rus. J. Bioorg. Chem., 2011, 37(3), pp. 261-269.

5. H. Vorbruggen, K. Krolikiewicz, and B. Bennua, Chem. Ber.,1981, 114, 1234.

6. A.A. Butt, S. Michaels, D. Greer, R. Clark, P. Kissinger and D.H. Martin, AIDS Read, 2002, 12: 317-321.

7. J.E. Spallholz .Free Radical Biol. Med., 1994, 17, pp. 45-64.
8. Ghosh, M.N., 2nd Edn., Scientific Book Agency, Kolkatta, ISBN: 81-902965-0-7, 1984, pp: 175-176.

9. S. Reitman, and Frankel, S., Am. J. Clin. Pathol., 1957, 28: 56-56.

10. H. U. Bergmeyer (Ed.). Verl. Chemie, Weinheim., 1974 V.76, Issue 5, P. 472

11. S. Rai, W. Atul, M. Kakal, P. Bishn. and M.Pulok., J. of Ethnopharma. 2006, 104, 322327.

12. W.H. Habig, M.J. Pabst, W.B. Jakoby, J. Biol. Chem.; 1974, 249(22-25): 7130-7139.

13. Kakkar, P., Das, B., Visvanathan, P.N., Indus. J. Biochem. and Biophys., 1972, 197, 588590.

14. G.L.Ellaman, Arch. Biochem. and Biophys. 1959. 82, 70-72.

15. M.M. Bradford, Anal.Biochem., 1976, 72: 248 -254 . 